AL IBTIDA: JURNAL PENDIDIKAN GURU MI (2018) Vol 5 (2) : 275-286

DOI: http://dx.doi.org/ 10.24235/al.ibtida.snj.v5i2.3397

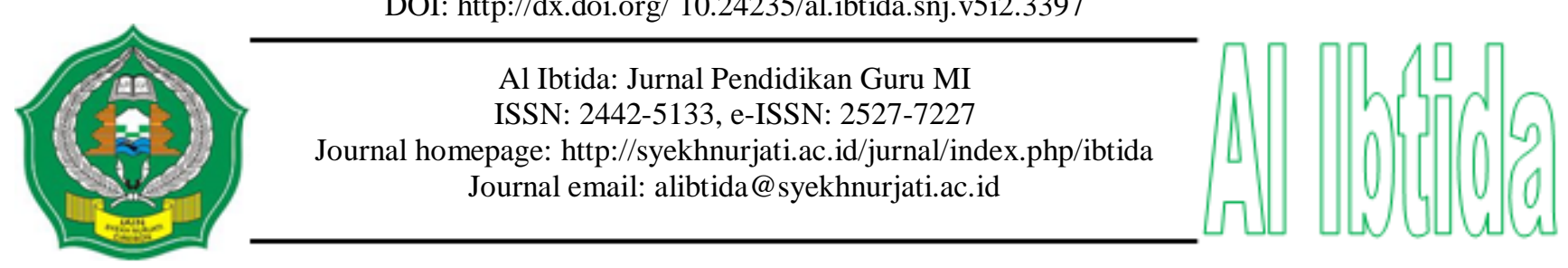

\title{
Upaya Meningkatan Motivasi Belajar Siswa dengan Menggunakan Media Gambar Pada Pembelajaran Tematik di Sekolah Dasar
}

\author{
Sita Ratnaningsih* \\ *Program Studi Pendidikan Guru Madrasah Ibtidaiyah, Fakultas Ilmu Tarbiyah dan Keguruan, \\ UIN Syarif Hidayatullah Jakarta \\ Email: sita@uinjkt.ac.id \\ Genasty Nastiti** \\ **Program Studi Pendidikan Guru Madrasah Ibtidaiyah, Fakultas Ilmu Tarbiyah dan Keguruan, \\ UIN Syarif Hidayatullah Jakarta \\ Email: genasty.satiti@gmail.com
}

Received 23 October 2018; Received in revised form: 28 October 2018; Accepted 29 October 2018

Publish Online: 31 October 2018

\begin{abstract}
Abstrak
Masalah dalam penelitian ini adalah rendahnya motivasi belajar siswa kelas II SDN Curug 01 Kota Depok dalam pembelajaran Tematik. Hal tersebut dikarenakan sistem pembelajaran yang diberikan guru di kelas tersebut masih kurang menarik, sehingga menyebabkan siswa kurang bersemangat dalam mengikuti pelajaran yang diberikan. Penelitian ini dilakukan dengan tujuan untuk meningkatkan motivasi belajar siswa kelas II SDN Curug 01 Kota Depok dalam pembelajaran Tematik dengan menggunakan media gambar. Metode penelitian ini adalah Penelitian Tindakan Kelas yang terdiri dari 2 siklus dan tiap siklus terdiri dari 4 tahap, yaitu perencanaan, pelaksanaan, observasi, dan refleksi. Teknik pengumpulan data dengan menggunakan observasi, wawancara, dan dokumentasi. Teknik analisis data dilakukan secara kualitatif dan kuantitatif menggunakan rumus prosentase (\%) data angket untuk melihat keberhasilan penerapan penggunaan media gambar di dalam kelas dalam rangka meningkatkan motivasi belajar siswa. Berdasarkan hasil pengamatan aktivitas guru dalam mengunakan media gambar pada siklus I diperoleh 74,58\%, sedangkan pada siklus II diperoleh 89,58\%. Hal tersebut menunjukkan peningkatan aktivitas guru dalam usaha meningkatkan motivasi belajar siswa serta aktivitas siswa. Dan hasil observasi motivasi belajar siswa terdapat peningkatan dari siklus I diperoleh $72,15 \%$ menjadi $85,24 \%$ pada siklus II. Hal ini berarti terjadi peningkatan rata-rata motivasi belajar siswa meningkat sebesar $15,09 \%$. Berdasarkan hasil penelitian yang didapatkan, maka dapat disimpulkan bahwa penerapan pembelajaran dengan menggunakan media gambar dapat meningkatkan motivasi belajar siswa pada pembelajaran tematik yang diberikan guru kepada siswa di sekolah tersebut.
\end{abstract}

Kata kunci: media gambar, motivasi belajar, pembelajaran tematik. 


\begin{abstract}
The problem in this study is the low learning motivation of second grade students at State Elementary School (SDN) Curug 01 Depok City in thematic learning. This is because the learning system provided by the teacher in the class is still less attractive, which causes students to be less eager to take part in the lessons. This research was conducted with the aim of enhancing the learning motivation of second grade students at State Elementary School (SDN) Curug 01 Depok City in thematic learning, using image media. This research method is Classroom Action Research which consists of 2 cycles and each cycle consists of 4 stages, namely planning, implementation, observation, and reflection. Data collection techniques using observation, interviews, and documentation. Data analysis techniques were carried out qualitatively and quantitatively using a percentage formula (\%) questionnaire data to see the successful application of the use of media images in the classroom in order to improve student learning motivation. Based on the results of observations of teacher activities in using media images in cycle I obtained $74.16 \%$ while in cycle II it was $87.91 \%$. This shows an increase in teacher activity in an effort to increase student motivation and student activity. And the results of observation of student learning motivation there is an increase from cycle I obtained $70.15 \%$ to $85.24 \%$ in cycle II. This means an increase in the average student learning motivation increased by $15.09 \%$. Based on the results of the research obtained, it can be concluded that the application of learning using image media can improve students' learning motivation in thematic learning had given by the teacher to students at the school.
\end{abstract}

Keywords: picture media, learning motivation, thematic learning.

\title{
PENDAHULUAN
}

Pembelajaran untuk tingkat Sekolah Dasar/ Madrasah Ibtidaiyah dengan model pembelajaran tematik sudah mulai diperbicangkan oleh para ahli pendidikan di Indonesia sejak tahun 1999. Menurut (Trianto, 2010), pembelajaran tematik yang merujuk pada Kurikulum Berbasis Kompetensi (KBK) dan Kurikulum Tingkat Satuan Pendidikan sudah diberlakukan sejak tahun 2005. Untuk Implementasi Pembelajaran tematik di sekolah dasar ada beberapa komponen yang perlu dibahas dahulu seperti metode, penilaian, media, langkah pembelajaran dan peran guru. Setelah itu akan dibahas langkah penyusunan Pembelajaran tematik serta contoh Matriks Tematik, Silabus dan RPP.

Sebagai seorang guru, tentunya lebih banyak tahu tentang kondisi yang dihadapinya di dalam kelas, guru seringkali menemukan siswa yang pasif saat pembelajaran tematik. Hal ini disebabkan karena guru kurang menyajikan materi pembelajaran tematik yang lebih menarik, kreatif, dan bermakna. Di samping itu, media pembelajaran yang digunakan harus dapat memberikan pengalaman yang menyenangkan dan memenuhi kebutuhan untuk meningkatkan motivasi belajar siswa. Oleh karena itu dalam proses pembelajaran tematik pendidik hendaknya dapat menyajikan pembelajaran yang efektif dan efisien sesuai pola pikir peserta didik dengan menerapkan berbagai menggunakan media serta membimbing peserta didik untuk mengembangkan motivasi belajarnya. 
Berdasarkan hasil wawancara yang dilakukan dengan guru kelas dan observasi di tempat penelitian, masalah yang ditemui pada saat kegiatan pembelajaran tematik di sekolah tersebut adalah banyaknya peserta didik yang mengobrol dan bercanda dengan temannya serta ada rasa kebosanan siswa terhadap pembelajaran tematik. Hal ini dapat terlihat dari perhatian siswa pada saat guru menjelaskan materi pembelajaran, partisipasi siswa dalam pembelajaran masih rendah, masih jarang siswa yang bertanya pada saat pembelajaran berlangsung, ketika guru meminta siswa untuk mengerjakan soal yang diberikan, siswa tidak mengerjakannya untuk mencari penyelesaian dari soal tersebut melainkan bercanda dengan temannya. Di dapat informasi dari guru yang mengajar di kelas, bahwa motivasi belajar siswa cukup rendah. Hal itu dibuktikan dengan sikap siswa yang menunjukkan kurang semangat dalam mengikuti proses pembelajaran tematik, dan kurangnya penggunaan media gambar pada proses pembelajaran sehingga motivasi belajar siswa berkurang. Minimnya kemampuan guru dalam membuat dan menggunakan media, menyebabkan banyak siswa mengalami kesulitan dalam proses belajar, karena materi yang dibahas membutuhkan daya ingatan, pengetahuan, dan kemampuan memahami yang cukup tinggi. Pengamatan yang dilakukan peneliti juga menunjukkan motivasi belajar siswa yang masih rendah, hasil tersebut dapat terlihat dari sehari-hari mereka melakukan proses belajar. Hal ini dapat terjadi disebabkan karena dalam pembelajaran tematik guru seringkali menggunakan metode ceramah dan dalam pembelajarannya guru jarang menggunakan media gambar. Sehingga kondisi belajar mengajar dikelas kurang bermakna. Siswa hanya sering mendengarkan.

Oleh karena itu, salah satu alternatif yang dapat digunakan untuk meningkatkan motivasi belajar siswa dalam pembelajaran tematik adalah dengan menggunakan media gambar dalam proses pembelajaran tematik. Menurut Gaggne yang dikutip oleh Sadiman (2009) menyatakan bahwa media adalah sebagai salah satu jenis komponen dalam lingkungaan siswa yang dapat merangsangnya untuk belajar. Media gambar adalah salah satu media visual yang sederhana yang dapat mempermudah cara belajar siswa. Media ini dapat dibuat, tidak terlalu mahal, serta mudah dipahami dan dimengerti siswa. Gambar dapat memberikan ide atau memberikan kejelasan mengenai sesuatu hal. Dengan menggunakan media gambar peserta didik lebih mudah dalam memahami pembelajaran.

Berdasarkan beberapa hasil penelitian terdahulu, media gambar juga mampu meningkatkan motivasi belajar siswa. Penelitian yang dilakukan oleh Istiningsih, Fauzy \& Nisa (2018) mengungkapkan bahwa penggunaan media gambar mampu meningkatkan motivasi belajar siswa, dimana pada siklus I ketercapaian motivasi belajar siswa sebesar 50,63\%. Dalam siklus II ketercapaian motivasi belajar siswa meningkat menjadi 80,85\%. Penelitian senada juga dilakukan oleh (Kholik, 2017), yang menunjukkan terjadi peningkatan ketuntasan belajar siswa 
setelah menggunakan media gambar dalam proses pembelajaran di kelas, yaitu pada tahap pra siklus sebesar 42,85\%. Siklus I ketuntasan hasil belajar mencapai 48,57\%, siklus II mencapai 77,14\% dan siklus III terjadi peningkatan hasil belajar sebesar 91,42\% . Pada siklus III sudah mencapai indikator kinerja yang ditetapkan, maka penelitian ini dikatakan berhasil. Hasil penelitiannya Kartiniwati (2014) \& Nursanti (2016) juga mengungkapkan bahwa penggunaan media gambar dapat meningkatkan motivasi belajar siswa. Penelitian ini bertujuan untuk meningkatkan motivasi belajar siswa kelas II SDN Curug 01 Kota Depok dalam pembelajaran Tematik dengan menggunakan media gambar. Melalui penelitian ini diharapkan motivasi belajar siswa meningkat dan media gambar dapat diterapkan secara maksimal sebagai media pembelajaran yang mampu memotivasi belajar siswa dan meningkatkan prestasi belajar siswa.

\section{METODE PENELITIAN}

Penelitian ini menggunakan metode penelitian tindakan kelas atau Clasroom Action Research, yaitu penelitian yang dilakukan di kelas dengan tujuan memperbaiki atau meningkatkan mutu praktik pembelajaran. Bogdan \& Biklen (1992) menjelaskan bahwa penelitian tindakan kelas adalah pengumpulan informasi sistematis yang dirancang untuk membawa perubahan sosial siswa di kelas. Selain itu, Cameron-Jones (1983) mendefinisikan penelitian tindakan kelas sebagai penelitian yang dilakukan oleh praktisi pendidikan dengan tujuan meningkatkan praktik profesional mereka dan memahami anak didik dengan lebih baik. Sesuai dengan itu Allwright, Dick., Bailey, \& Kathlen (1991) menyebutkan bahwa penelitian tindakan kelas adalah pusat penelitian yang dilakukan di kelas, dan hanya mencoba menyelidiki apa yang sebenarnya terjadi pada siswa yang ada di dalam kelas. Langkah-langkah dalam penelitian tindakan kelas ini dilakukan melalui siklus dan dirancang menjadi empat langkah. Kemmis dan Taggart (1988) menyatakan bahwa penelitian dimulai dengan merencanakan suatu tindakan. Kemudian rencana tersebut diimplementasikan sebagai tindakan di kelas dan tindakannya kemudian diamati. Refleksi dilakukan untuk menganalisis data yang diperoleh selama tindakan.

Penelitian ini memfokuskan pada pembelajaran tematik pada Tema 1 di Subtema 1 di kelas II SDN Curug 01 Kota Depok, yang berjumlah 33 Siswa terdiri dari 12 siswa laki-laki dan 21 siswa perempuan, dengan proses pembelajaran dengan menggunakan media gambar. Penelitian ini bertujuan untuk memperbaiki pengembangan profesional guru dalam meningkatkan motivasi belajar siswa terhadap proses pembelajaran di kelas melalui satu tindakan tertentu serta mampu memberi pendapat mereka secara perorangan maupun secara keseluruhan. Terdapat faktor yang ditetapkan sebagai acuan keberhasilan penelitian ini adalah indikator keberhasilan penggunaan media gambar, apabila semua siswa sudah dapat terlibat 
secara aktif, terbuka, dan termotivasi. Penelitian ini memiliki empat tahapan kegiatan pada setiap siklus, yaitu: (1) Perencanaan tindakan, (2) Pelaksanaan tindakan, (3) Observasi atau pengamatan, dan (4) refleksi dan evaluasi untuk memperoleh sejauh mana pencapaian hasil yang diharapkan, kemudian direvisi untuk melaksanakan tindakan pada siklus berikutnya.

Teknik pengumpulan data yang digunakan untuk memperoleh data penelitian adalah melalui: 1) Obseservasi, yaitu mengadakan pengamatan terhadap proses pembelajaran secara langsung tentang masalah yang akan diteliti, kemudian dibuat catatan sesuai hasil tersebut. Jenis observasi yang digunakan adalah observasi langsung untuk mengetahui proses penggunaan media gambar dan motivasi belajar siswa; 2) wawancara, digunakan untuk mencari data awal mengenai masalah yang dihadapi guru maupun siswa dalam pelajaran tematik, selain itu untuk mendapatkan data mengenai tanggapan siswa ataupun guru terhadap proses tindakan yang suka dilakukan; 3) dokumentasi, berupa foto proses pembelajaran dengan menggunakan media gambar dalam pembelajaran tematik untuk memotivasi siswa dalam belajar.

Sementara itu, data hasil penelitian ini dianalisis secara kualitatif dan kuantitatif menggunakan analisis data angket yang dinyatakan dalam bentuk prosentase (\%), untuk melihat keberhasilan penerapan penggunaan melalui media gambar di dalam kelas dalam rangka meningkatkan motivasi belajar siswa. Sebelum melaksanakan analisis, peneliti melakukan pengolahan seluruh data yang diperoleh terkait dengan keterlaksanaan pembelajaran menggunakan rumus NA $=\frac{A}{B} \times 100 \%$, dimana NA $=$ Prosentase keterlaksanaan pembelajaran, $\mathrm{A}=$ Jumlah ckecklist pada tahapan pembelajaran, dan $\mathrm{B}=$ Jumlah keseluruhan tahap pembelajaran dan hasil observasi motivasi belajar siswa dengan menggunakan rumus $N A=\frac{A}{B} \times$ $100 \%, \mathrm{NA}=$ Nilai akhir prosentase motivasi, $\mathrm{A}=$ Jumlah skor pencapaian, dan $\mathrm{B}=$ Skor maksimum.

\section{HASIL DAN PEMBAHASAN}

\section{Hasil Penelitian}

Berdasarkan hasil observasi yang dilakukan oleh peneliti terkait dengan aktivitas guru dan siswa dalam proses pembelajaran tematik menggunakan media gambar dapat dilihat pada data hasil observasi aktivitas guru dan siswa pada siklus I dan siklus II. Adapun data hasil observasi aktivitas guru dan siswa pada siklus I dan siklus II dapat disajikan pada grafik 1. 
Grafik 1. Rekapitulasi Hasil Observasi Aktivitas Guru Siklus I

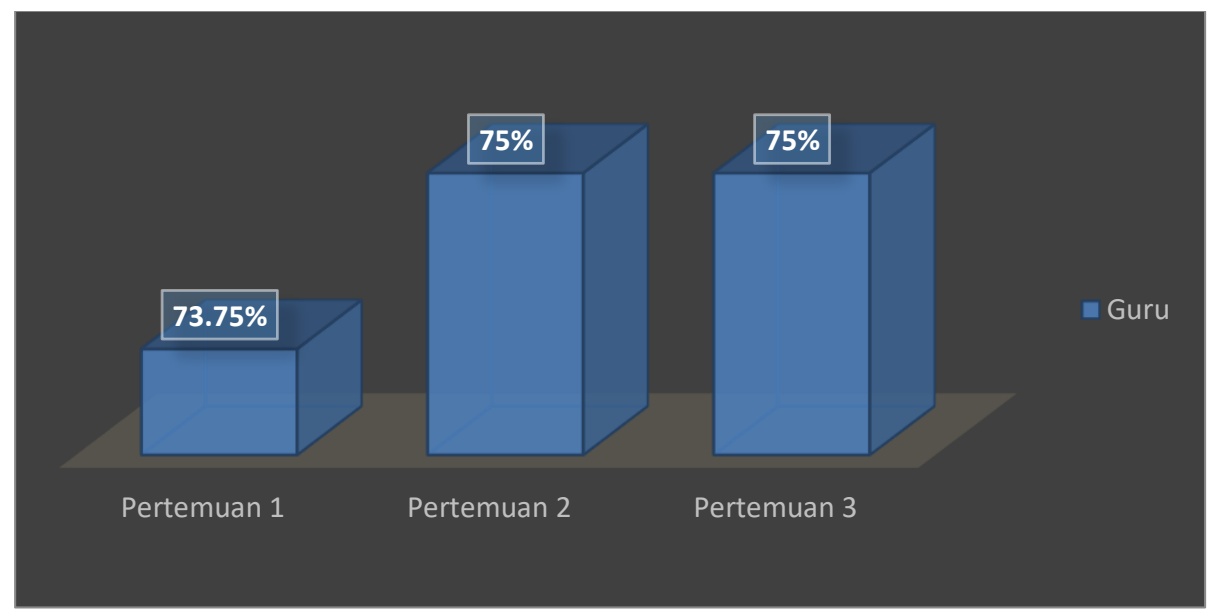

Berdasarkan grafik 1 terlihat bahwa persentase aktivitas guru dalam proses pembelajaran tematik menggunakan media gambar pada siklus I diperoleh rata-rata sebesar 74,58\% dan berada pada kategori baik, karena berada pada interval 50\% - 75\%. Adapun pada siklus II hasil perolehan aktivitas mengajar guru dalam menerapkan media gambar mengalami peningkatan yaitu berada pada katagori sangat baik. Berikut grafik rekapitulasi hasil observasi aktivitas mengajar guru pada siklus II.

Grafik 2. Rekapitulasi Hasil Observasi Aktivitas Guru Siklus II

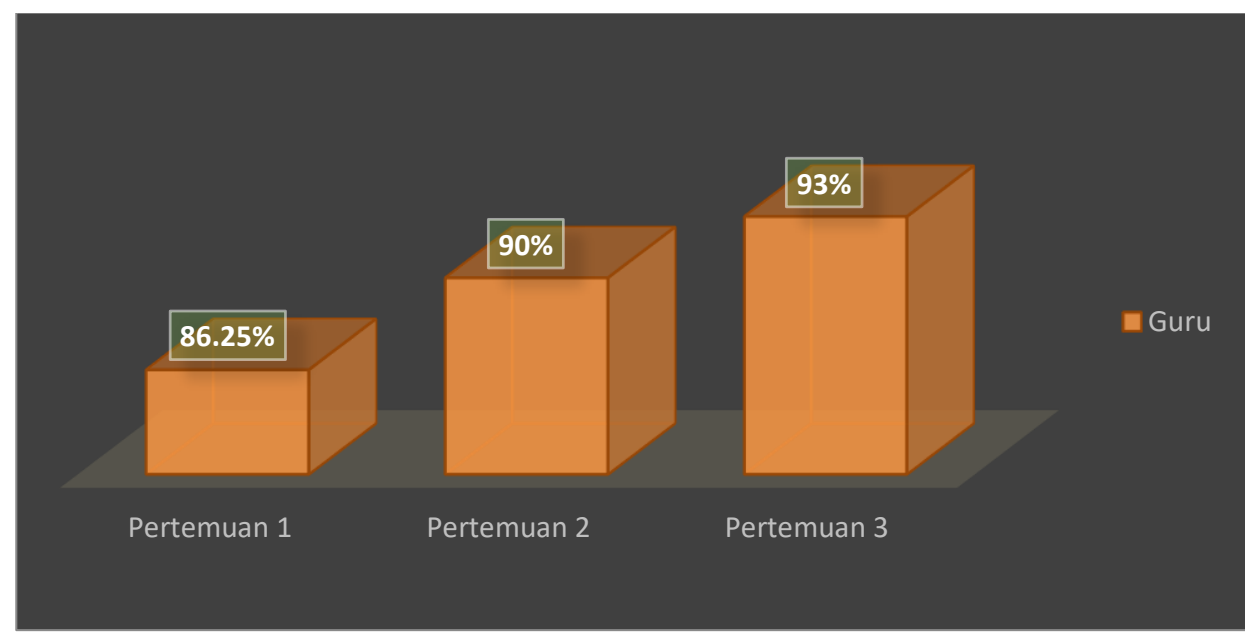

Pada grafik 2 menunjukkan bahwa persentase aktivitas guru dalam proses pembelajaran tematik menggunakan media gambar/foto pada siklus II diperoleh rata-rata sebesar 89,75 dan berada pada kategori sangat baik. Hasil tersebut dapat disimpulkan bahwa pada siklus II aktivitas belajar siswa pada pembelajaran tematik dengan menggunakan media gambar yang telah diterapkan berlangsung dengan baik.

Adapun hasil perolehan aktivitas belajar siswa pada pembelajaran tematik menggunakan media gambar dapat dilihat pada grafik 3 . 
Grafik 3. Rekapitulasi Hasil Observasi Aktivitas Siswa Siklus I

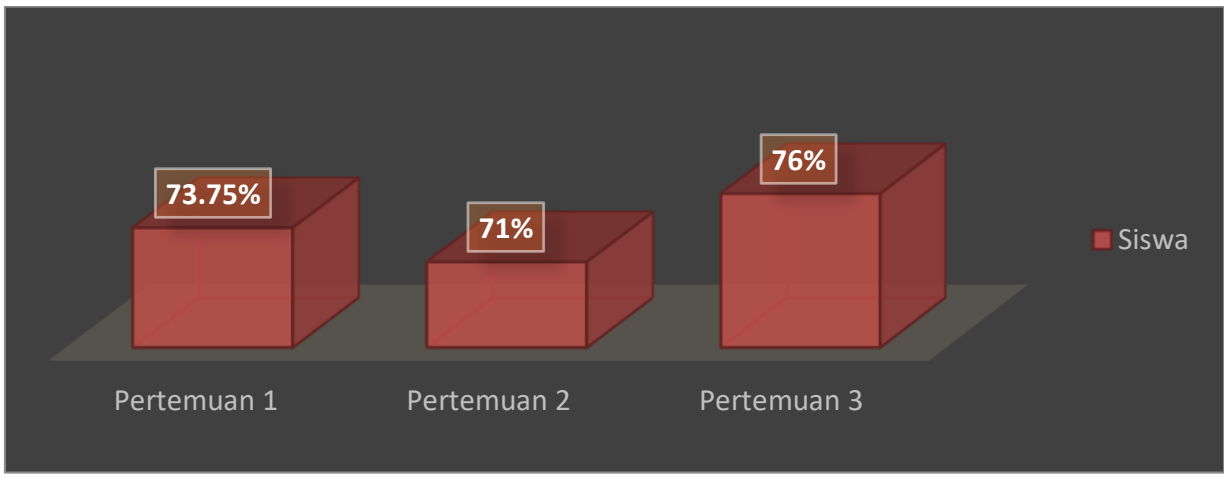

Berdasarkan grafik 3 hasil observasi aktivitas siswa pada siklus I diperoleh persentase aktivitas belajar siswa pada siklus I rata-rata sebesar 73,58\% dan berada pada kategori baik. Hal ini berarti bahwa siswa sudah berperan aktif dalam proses pembelajaran tematik menggunakan media gambar. Sementara itu, hasil observasi aktivitas belajar siswa dalam pembelajaran tematik pada siklus II dapat disajikan pada grafik 4 berikut.

Grafik 4. Rekapitulasi Hasil Observasi Aktivitas Siswa Siklus II

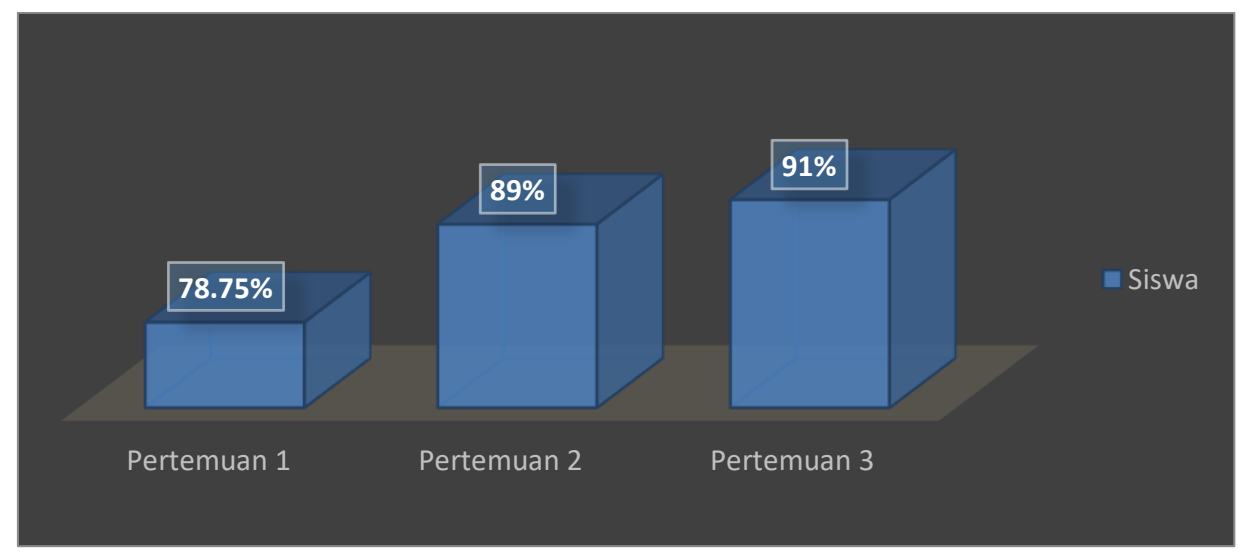

Pada grafik 4 terlihat bahwa hasil observasi aktivitas siswa pada siklus II diperoleh persentase rata-rata sebesar $86,25 \%$ dan berada pada kategori sangat baik. Hal ini berarti bahwa siswa sudah sangat berperan aktif dalam proses pembelajaran tematik menggunakan media gambar. Jadi dapat disimpulkan bahwa pada siklus II aktivitas belajar siswa pada pembelajaran tematik dengan menggunakan media gambar berlangsung dengan sangat baik.

Adapun rekapitulasi hasil observasi aktifitas guru dan siswa dalam pembelajaran tematik dengan menggunakan media gambar sebagaimana tabel 1 berikut.

Tabel 1. Rekap Hasil Observasi Aktivitas Guru dan Siswa

\begin{tabular}{|c|c|c|c|}
\hline No & Hasil Proses Pembelajaran & $\begin{array}{l}\text { Siklus I } \\
(\%)\end{array}$ & $\begin{array}{l}\text { Siklus II } \\
(\%)\end{array}$ \\
\hline 1. & $\begin{array}{l}\text { Hasil observasi aktivitas } \\
\text { guru }\end{array}$ & $74,58 \%$ & $89,75 \%$ \\
\hline 2. & $\begin{array}{l}\text { Hasil observasi aktivitas } \\
\text { belajar siswa }\end{array}$ & $73,58 \%$ & $86,25 \%$ \\
\hline \multicolumn{2}{|c|}{ Rata-rata } & $74,08 \%$ & $88,00 \%$ \\
\hline
\end{tabular}


Pada tabel 1 terlihat bahwa hasil obervasi aktivitas guru pada siklus I diperoleh sebesar $74,58 \%$ dan pada siklus II diperoleh sebesar 89,75\%. Hal tersebut menunjukkan adanya peningkatan aktivitas guru dalam usaha meningkatkan motivasi belajar siswa dalam pembelajaran tematik sebesar $15,17 \%$. Sementara itu, hasil observasi aktivitas belajar siswa untuk mengukur motivasi belajar siswa dari siklus I yang memperoleh 73,58\% menjadi 86,25\% pada siklus II. Hal ini berarti bahwa terjadi peningkatan rata-rata motivasi belajar siswa dari siklus I ke siklus II sebesar 13,92\%.

\section{Pembahasan}

Pada dasarnya dalam proses pembelajaran yang dilakukan oleh seorang guru dengan siswa, ada hubungan antara motivasi belajar siswa dengan hasil belajarnya. Menurut (Biggs, 2003) mengemukakan bahwa bahwa hasil belajar siswa sangat tergantung pada pengetahuan awal siswa dan faktor-faktor yang memotivasi mereka untuk belajar. Sedangkan menurut Schunk, Pintrich \& Meece (2008) menyatakan bahwa motivasi belajar adalah proses yang mengharuskan siswa untuk melakukan aktivitas fisik atau mental untuk mencapai tujuan mereka. Sehubungan dengan hal tersebut, menurut Pintrich (1999) dan Kang (2008) menyatakan bahwa pembelajaran muncul dari interaksi antara variabel kognitif dan tingkat motivasi belajar yang di punyai oleh siswa.

Ryan \& Deci (2000) mendefinisikan motivasi intrinsik sebagai motivasi yang berasal dari individu. Menurut para pakar tersebut, siswa yang termotivasi secara intrinsik belajar karena didorong oleh rasa kepuasan batin. Motivasi ekstrinsik menurut Walker, Barbara \& Robert (2006) mengacu pada motivasi yang dihasilkan oleh faktor-faktor eksternal yang ada di sekitar siswa dan mempengaruhi siswa. Beberapa teori tentang motivasi siswa yang disampaikan oleh Bandura (1997), Pintrich \& DeGroot (1990), Pintrich \& Schunk menekankan bahwa motivasi belajar dipengaruhi oleh adanya faktor harapan siswa, nilai yang diperoleh dan pengaruh yang menjadikan motivasi belajar siswa menjadi meningkat atau menurun. Harapan mengacu pada keyakinan siswa mengenai apa yang ingin mereka capai dengan melakukan tugas tertentu. Nilai berpengaruh pada alasan mengapa siswa menjadi semangat untuk belajar, melakukan tugas akademik tertentu dan perolehan akhir mereka belajar. Adapun pengaruh yang menjadikan motivasi belajar menjadi meningkat dapat dipengaruhi dari berbagai faktor, salah satu nya adalah dengan penggunaan media gambar seperti yang dilakukan dalam penelitian ini.

Pada penelitian ini peneliti memfokuskan pada peningkatan motivasi belajar siswa dengan menggunakan media gambar pada pembelajaran tematik kelas II SDN Curug 01 Kota Depok. Berdasarkan analisis data kegiatan selama proses pembelajaran berlangsung dimulai dari siklus I yakni dengan menggunakan media gambar maka terlihat adanya peningkatan motivasi 
belajar siswa yakni ditunjukkan dengan rata-rata hasil observasi aktivitas belajar siswa siklus I sebesar 73,58\%. Namun hasil observasi aktivitas belajar siswa tersebut belum menunjukkan hasil maksimal dimana ada yang belum mencapai prosentase yang diharapkan. Maka dilakukan siklus II dengan memperbaiki kekurangan pada siklus I. dan pada siklus II hasil observasi aktivitas belajar siswa pada pembelajaran Tematik dengan menggunakan media gambar mencapai presentase yang maksimal, hal ini juga dibuktikan dengan meningkatnya aktivitas belajar siswa yang terlihat saat proses pembelajaran.

Dari analisis data pengamatan aktivitas guru dapat dilihat usaha guru untuk meningkatkan motivasi belajar siswa pada siklus II mencapai $89,75 \%$. Hal ini sangat berperan dalam meningkatkan aktivitas siswa yang juga mencapai $86,25 \%$. Artinya bahwa motivasi dapat dirangsang oleh faktor dari luar peserta didik, karena itu dalam proses pembelajaran guru harus dapat menggunakan metode, strategi, dan pendekatan yang variatif serta menggunakan media yang tepat sehingga motivasi yang ada dalam diri anak muncul karena ada rasa membutuhkan dan mempunyai rasa ingin tahu yang tinggi. Dengan menggunakan media pembelajaran seperti media gambar dalam pembelajaran tematik ternyata dapat membuat siswa termotivasi dan siswa cenderung lebih aktif terutama dalam membaca dan memahami pelajaran, sehingga dapat mempengaruhi prestasi belajar siswa.

Hal ini diperkuat dengan hasil penelitiannya Posia, Jamaluddin, \& Harun (2016) yang menyatakan bahwa penerapan pembelajaran dengan menggunakan media gambar dapat meningkatkan motivasi belajar siswa pada mata pelajaran IPS kelas IV SD Negeri 6 Tolitoli sebesar $76 \%$ pada siklus I dan mengalami peningkatan pada siklus II menjadi $100 \%$. Penelitian serupa juga dilakukan oleh Sukri, Umar, \& Tandililing (2000) yang menunjukkan bahwa penggunaan media gambar dalam pembelajaran tematik tema "selalu berhemat energi" yang dilaksanakan dengan terencana, sistematis, konsisten baik dan terarah dengan benar akan memperoleh hasil yang memuaskan. Hasil penelitian yang senada juga pernah dilakukan oleh Rodgers, David, \& Thorton (2005) yang menyatakan bahwa penggunaan media pembelajaran dapat meningkatkan motivasi belajar siswa.

Upaya meningkatkan motivasi belajar dan hasil belajar siswa pada pembelajaran Tematik di Sekolah Dasar juga digunakan dengan cara, metode, dan pendekatan yang berbeda. Seperti penelitian yang dilakukan oleh Masnun (2016), yang menyatakan bahwa untuk mencapai kualitas pembelajaran yang telah dirancang, maka dalam dokumen kurikulum kegiatan pembelajaran perlu menggunakan prinsip yang: (1) berpusat pada peserta didik, (2) mengembangkan kreativitas peserta didik, (3) menciptakan kondisi menyenangkan dan menantang, (4) bermuatan nilai, etika, estetika, logika dan kinestetika, dan (5) menyediakan 
pengalaman belajar yang beragam melalui penerapan berbagai strategi dan metode pembelajaran yang menyenangkan, kontekstual, efektif, efisien dan bermakna. Sehingga dengan menggunakan langkah-langkah dalam pembelajaran Saintik yang diterapkan pada pembelajaran tematik di sekolah Dasar, diharapkan dapat menjadi salah satu faktor untuk meningkatkan motivasi belajar dan hasil belajar yang diperoleh siswa.

Selain media gambar, untuk meningkatkan motivasi belajar siswa juga dilakukan dengan menggunakan video, seperti penelitian yang dilakukan oleh Ibarra, García, Guzmán, Enache, \& Alarcón yang berjudul "Video as a New Teaching Tool to Increase Student Motivation". Dalam penelitian tersebut dinyatakan bahwa studi ini berdasarkan pada pemakaian beberapa video streaming yang dibuat sebagai bahan pendukung untuk belajar dan digunakan oleh 12 pengajar dengan 487 siswa di Sekolah Industri dan Teknik Aeronautika Terrassa (ETSEIAT). Dengan cara yang inovatif tersebut dapat disimpulakan bahwa alat pembelajaran dengan bantuan media video tersebut memberikan dampak yang luar biasa pada semangat belajar siswa, sehingga prestasi belajarnya meningkat secara signifikan setelah diterapkan pembelajaran dengan bantuan media tersebut di kelas.

Tulisan yang lain tentang peningkatan motivasi belajar adalah dengan memanfaatkan Teknologi Informasi dan Komunikasi (TIK) di sekolah. Review artikel dengan judul "Effective use of ICT for Education and Learning by Drawing on Worldwide Knowledge, Research, and Experience: ICT as a Change Agent for Education", yang di tulis oleh (Noor-Ul-Amin, 2013) menyatakan bahwa Teknologi informasi dan komunikasi (ICT) telah menjadi entitas umum di semua aspek kehidupan. Selama dua puluh tahun terakhir penggunaan TIK telah secara mendasar mengubah praktik dan prosedur dari hampir semua bentuk usaha dalam bisnis dan pemerintahan. Bidang pendidikan telah dipengaruhi oleh TIK, yang tidak diragukan telah mempengaruhi pengajaran, pembelajaran, dan penelitian (Yusuf, 2005).

Banyak penelitian telah membuktikan manfaat TIK bagi kualitas pendidikan (Al-Ansari, 2006). TIK memiliki potensi untuk berinovasi, mempercepat, memperkaya, dan memperdalam keterampilan, untuk memotivasi dan melibatkan siswa, untuk membantu menghubungkan pengetahuan dari sekolah dengan praktik kerja, menciptakan kelayakan ekonomi bagi pekerja masa depan, serta memperkuat pengajaran dan membantu sekolah untuk menjadi lebih maju (Davis dan Tearle, 1999), Lemke \& Coughlin yang dikutip oleh (Yusuf 2005). Di samping itu hasil penelitian tersebut menyatakan banyak hasil penelitian yang dilaporkan tentang dampak dari pembelajaran TIK bagi teknologi, terutama komputer, dalam pendidikan yang diberikan pada siswa. 


\section{SIMPULAN}

Berdasarkan perolehan hasil penelitian tindakan kelas yang telah dilakukan selama dua siklus yang terdiri dari 6 pertemuan. Mengenai penggunaan media gambar pada pembelajaran tematik kelas II SDN 01 Curug Kota Depok. Menunjukkan adanya peningkatan motivasi peserta didik. Hasil tersebut dapat dilihat pada analisis data aktivitas guru siklus I pertemuan 1 sebesar 73,75\%, pertemuan 2 sebesar 75\%, pertemuan 3 sebesar 75\%. Maka dapat disimpulkan rata-rata perolehan data aktivitas guru mengajar peserta didik pada siklus I adalah 74,58\%. Pada siklus II perolehan dari hasil analisis data pada pertemuan 1 sebesar $86,25 \%$, pertemuan 2 sebesar 90\%, dan pertemuan 3 sebesar 93\%. Maka dapat disimpulkan rata-rata perolehan data pada siklus II adalah $89,75 \%$. Sementara itu, pada analisis data dari aktivitas siswa siklus I pertemuan 1 sebesar $73,75 \%$, siklus I pertemuan 2 sebesar $71 \%$, dan siklus I pertemuan 3 sebesar $76 \%$, maka dapat disimpulkan rata-rata perolehan data pada aktivitas siswa siklus I 73,58\%. Pada siklus II perolehan dari hasil analisis data pada pertemuan 1 sebesar 78,75\%, pertemuan 2 sebesar 89\%, dan pertemuan 3 sebesar 91\%. Maka dapat disimpulkan rata-rata perolehan data dari aktivitas siswa pada siklus II adalah 86,25\%. Dengan demikian maka penggunaan media gambar pada pembelajaran tematik dapat meningkatkan motivasi belajar siswa di sekolah dasar SDN 01 Curug Kota Depok.

\section{DAFTAR PUSTAKA}

Al-Ansari, H. (2006). Internet Use by the Faculty Members of Kuwait University. The Electronic Library, 24(6), 791-803.

Allwright, Dick., Bailey, \& Kathlen, M. (1991). Focus On The Language Classroom An Introduction To Classroom Research For Language Teachers. Cambridge: Cambridge University Press

Bandura, A. (1997). Self-efficacy: The Exercise of Control. New York: Freeman.

Biggs, J. (2003). Teaching for Quality Learning at University (2nd ed), Open University Press.

Bogdan, R. C,. \& Biklen, S. K. (1992). Qualitative Research for Education An Introduction To Theory and Methods. London: Allyn and Bacon.

Cameron, J. (1983). A Searching profession? The Growth of Classroom Action Research. Scotland: Moray house College of Education

Davis, N.E., \& Tearle, P. (Eds.). (1999). A Core Curriculum for Telematics in Teacher Training. Available: www.ex.ac.uk/telematics.T3/corecurr/tteach98.htm

Ibarra, E. R. B., García, B. A., Guzmán, P. S., Enache, C. M., \& Alarcón, V. F. (2011). Video as a new teaching tool to increase student motivation. In IEEE EDUCON 2011.

Istiningsih, S., Fauzy, M., \& Nisa, K. (2018). Penggunaan Media Gambar Untuk Meningkatkan Motivasi Belajar Matematika Pada Siswa Kelas 1 SDN 1 Kediri Tahun Pelajaran 2017/2018. JKKP (Jurnal Kesejahteraan Keluarga dan Pendidikan), 5(1), 31-41. 
Kang, S., Scharmann, L.C., Noh, T. \& Koh, H. (2008). The influence of students' cognitive and motivational variables in respect of cognitive conflict and conceptual change. International Journal of Science Education, 27, 1037-1058.

Kartiniwati, K., \& Husni, M. (2014), Penggunaan Media Gambar Untuk Peningkatan Motivasi dan Hasil Belajar Bercerita Tema Lingkungan Siswa di Sekolah Dasar. PGSD FIP Universitas Negeri Surabaya.

Kemmis, S \& Taggart, R. (1988). The Action Research Planner. Victoria: Deakin University.

Kholik, B. (2017). Penggunaan Media Gambar dalam Upaya Meningkatkan Motivasi dan Hasil Belajar Siswa pada Tema Tempat Tinggalku (Penelitian Tindakan Kelas dilaksanakan di Kelas IV SDN Rancasawo 1 Kota Bandung Pada Tema Tempat Tinggalku Subtema Lingkungan Tempat Tinggalku) (Doctoral dissertation, FKIP Unpas)

Masnun, M. (2016). Penerapan Pendekatan Saintifik dalam Pembelajaran Tematik Terpadu. $A l$ Ibtida: Jurnal Pendidikan Guru MI, 3(1). 93-115

Noor-Ul-Amin, S. (2013). An effective use of ICT for education and learning by drawing on worldwide knowledge, research, and experience: ICT as a change agent for education. Scholarly Journal of Education, 2(4), 38-45

Nursanti, R. (2016). Penggunaan Media Gambar Dalam Upaya Meningkatkan Motivasi dan Hasil Pembelajaran Dengan Tema Indahnya Kebersamaan Pada Sub Tema Keberagaman Budaya Bangsaku, FKIP Universitas Pasundan, Bandung.

Pintrich, P. \& DeGroot, E. V. (1990). Motivational and self-regulated learning components of classroom academic performance, Journal of Educational Psychology, 82, 33-40.

Pintrich, P. \& Schunk, D.H. (2002). Motivation in Education, Upper Saddle River, NJ: Merrill Prentice Hall.

Pintrich, P. (1999). The role of motivation in promoting and sustaining self regulated learning, International Journal of Educational Research. 3(1), 459-470.

Posia, Jamaluddin, \& Harun. (2016) Penggunaan Media Gambar Untuk Meningkatkan Motivasi Belajar Siswa dalam Pembelajaran IPS Siswa Kelas IV SD Negeri 6 Tolitoli. Jurnal Kreatfi Tadulako Online, 4 (3), 83-94

Rodgers, David, L., \& Thorton, W. (2005). The Effect of Instructional Media on Learner Motivation, Beverly J International Journal of Instructional Media, 2(1), 206-217.

Ryan, R.M. \& Deci, E. L. (2000). Self-determination theory and the facilitation of intrinsic motivation, social development, and well-being, American Psychologist, 55, 68-78.

Sadiman, A. (2009). Media Pendidikan Pengertian, Pengembangan, Pemanfaatannya. Jakarta: Rajawali Pers.

Schunk, D. H., Pintrich, P. R. \& Meece, J. L. (2008). Motivation in education: Theory, Research, and Applications (3rd ed.), Upper Saddle River, NJ: Merrill Prentice Hall.

Sukri, Umar, S., \& Tandililing, E. Implementasi Pembelajaran Tematik Melalui Media Gambar Untuk Perolehan Belajar SD. Jurnal Pendidikan dan Pembelajaran, 6(3).

Trianto. (2010). Mengembangkan Model Pembelajaran Tematik. Jakarta: Prestasi Pustaka

Walker, A., Barbara, C. \& Robert, A. (2006). Identification with academics,intrinsic/extrinsic motivation, and self-efficacy as predictors of cognitive engagement. Learning and Individual Differences Journal, 16, 1-12.

Yusuf, M. O. (2005). Information and communication education: Analyzing the Nigerian national policy for information technology. International Education Journal, 6(3), 316 